\title{
Seasonal variations of the water soluble organic carbon mass fraction of aerosol in two valleys of the French Alps
}

\author{
J.-L. Jaffrezo ${ }^{1}$, G. Aymoz ${ }^{1}$, C. Delaval ${ }^{1}$, and J. Cozic ${ }^{1, *}$ \\ ${ }^{1}$ Laboratoire de Glaciologie et Géophysique de l'Environnement (LGGE), 54 rue Molière, 38402 Saint Martin d'Hères \\ Cedex, France \\ *now at: Laboratory for Atmospheric Chemistry, Paul Scherrer Institute, 5232 Villigen, PSI, Switzerland
}

Received: 24 February 2005 - Published in Atmos. Chem. Phys. Discuss.: 16 May 2005

Revised: 26 September 2005 - Accepted: 6 October 2005 - Published: 27 October 2005

\begin{abstract}
Concentrations of Water Soluble Organic Carbon (WSOC) and WSOC fraction to Organic Carbon (OC) were measured at two urban sites in valleys of the French Alps during a period of two and a half years. Concentrations were as high as $10-15 \mu \mathrm{g} \mathrm{C} / \mathrm{m}^{3}$ in winter, but there is a clear seasonal cycle of the WSOC fraction, with minima occurring during winter. This reflects a marked dependency on temperature, with the average WSOC fraction being stable at $54.8 \pm 7.7 \%$ and $75.9 \pm 6.3 \%$ for temperatures in the ranges -10 to $+3{ }^{\circ} \mathrm{C}$ and 12 to $24^{\circ} \mathrm{C}$, respectively. Several points are noteworthy in this evolution. First, there are limiting factors that prevent lower mass fractions in the low temperature range and higher mass fractions in the high temperature range. Second, the mass fraction at the lower temperature is rather high, in apparent contradiction with OC being mainly insoluble close to the emission sources. Third, the range of $20 \%$ for the change of the WSOC fraction between these extreme conditions is indeed rather narrow when compared to evaluations of the secondary (and supposedly water soluble) OC fraction proposed in the literature, with most of the published values being in the range 40 to $70 \%$. A comparison of the evolution of WSOC concentrations with that of dicarboxylic acids (DCA) clearly indicates the influence of two regimes in the formation of WSOC: one at higher temperatures classically linked with the increase of DCA concentrations and associated with oxidation processes, and another at lower temperatures involving a much lower increase of DCA concentrations. We proposed several hypotheses involving processes that could be responsible for the large concentrations of WSOC in the particulate phase at our sites during winter time.
\end{abstract}

Correspondence to: J.-L. Jaffrezo

(jaffrezo@lgge.obs.ujf-grenoble.fr)

\section{Introduction}

Few studies have focused on the Water Soluble Organic Carbon (WSOC) fraction of atmospheric particles, even though this fraction is probably of the utmost importance for aspects related to global climate (Kanakidou et al., 2005, and references therein) and the impact of aerosols on human health (Turpin, 1999; Dreher, 2000). Several investigations are currently available in the literature that outline studies conducted in urban or rural environments. However, the number of samples in most of these studies is rather low (see Sect. 3), and little ancillary data exists to delineate the respective impacts of sources and aging on the evolution of WSOC concentrations and of the mass fraction relative to Organic Carbon (OC). Furthermore, these data were obtained using a large array of methods, both in relation to the collection of samples and to the analyses of OC and WSOC concentrations, making comparisons and the construction of an overall picture rather difficult. The current belief maintains that the WSOC fraction is "low" for primary OC and that it increases with aging of the aerosol, together with the general oxidation state of Organic Matter (OM) (Saxena and Hildemann, 1996; Decesari et al., 2001). However, this idea has not been substantiated by many comprehensive field studies, and in particular, no full seasonal cycle of WSOC is currently published that presents data derived from homogeneous collection and analytical methods for various environmental conditions.

The program POVA (Pollution des Vallées Alpines) was launched in 2000 to focus on atmospheric chemistry in the two transit corridors between France and Italy: the Chamonix and Maurienne Valleys. This study was timed to take advantage of a unique opportunity: the "Tunnel du Mont Blanc" (TMB) in the Chamonix Valley was closed for nearly 3 years after a large accident in March 1999. During this time period, most of the heavy-duty traffic in the area was re-routed through the "Tunnel du Fréjus", in the

(C) 2005 Author(s). This work is licensed under a Creative Commons License. 


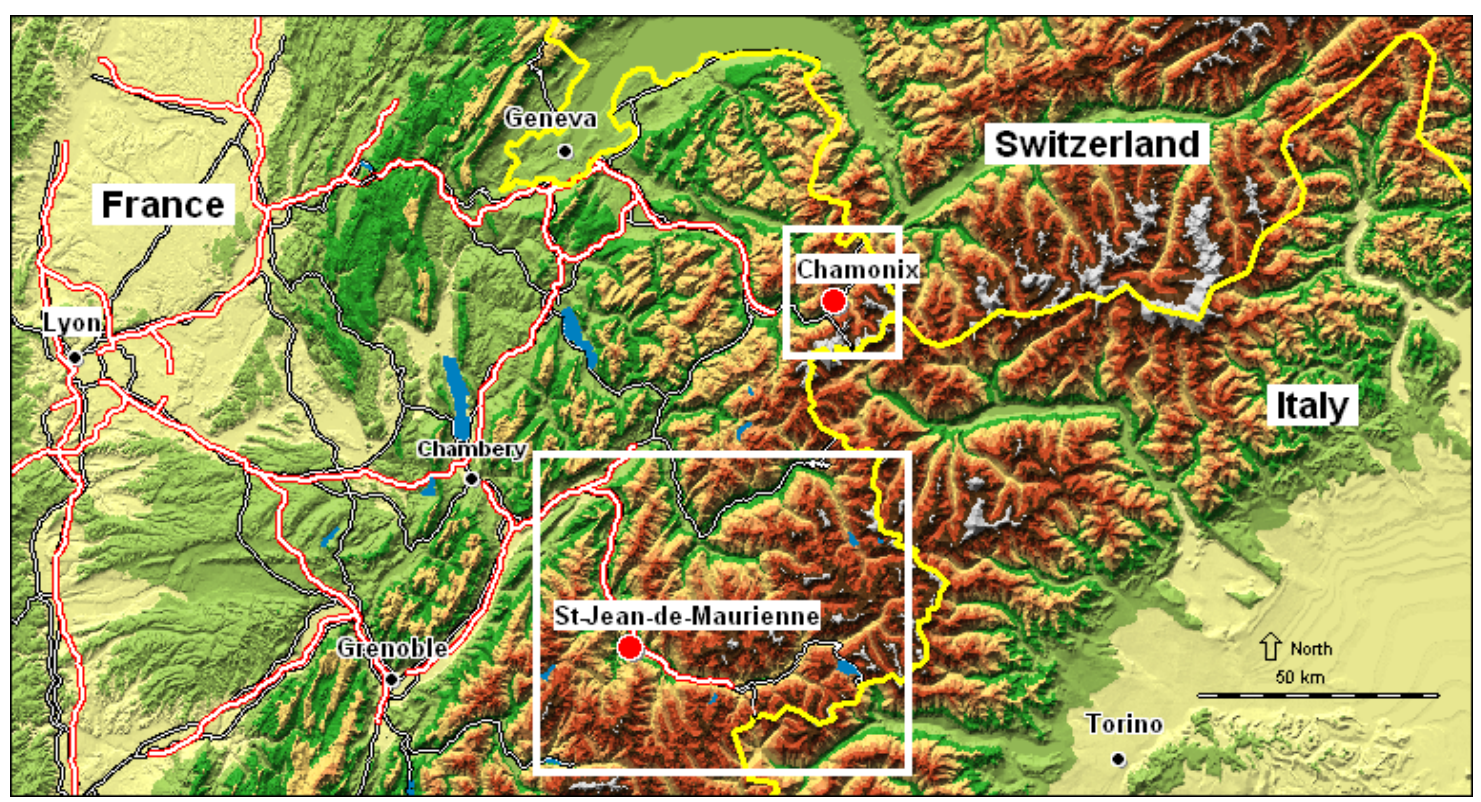

Fig. 1. Sampling areas in the French Alps.

Maurienne Valley. The general goal of the POVA program was to compare the air quality and modelled atmospheric emissions and transport in these two valleys before and after the re-opening of the TMB to heavy-duty traffic. The program included several intensive field campaigns, a long-term campaign, and 3-D modelling of atmospheric dynamics and chemistry (Brulfert et al., 2005a).

In this paper, we are presenting results of WSOC measurements conducted on samples obtained during the longterm sampling at one site in each valley. Other publications present discussions of the concentrations of Elemental Carbon (EC) and OC (Aymoz, 2005; Jaffrezo et al., 2005b ${ }^{1}$ ), and of ionic species (Jaffrezo et al., 2005 $\mathrm{c}^{2}$ ) obtained at the same time. Here, we are aiming at an evaluation of the variability of the WSOC concentration and mass fraction in this study, and will make an attempt to understand the main factors and processes driving this variability. In a first part, we are presenting some tests performed to evaluate the experimental aspects of WSOC measurements.

\footnotetext{
1 Jaffrezo, J. L., Aymoz, G., Cozic, J., Chapuis, D., and Maenhaut, W.: Seasonal variation of $\mathrm{PM}_{10}$ main constituents in two valleys of the French Alps. I: EC/OC fractions, Atmos. Chem. Phys. Discuss., in preparation, 2005b.

${ }^{2}$ Jaffrezo, J. L., Aymoz, G., and Cozic, J.: Seasonal variation of $\mathrm{PM}_{10}$ main constituents in two valleys of the French Alps. II: Ionic constituents, Atmos. Chem. Phys. Discuss., in preparation, 2005c.
}

\section{Experimental}

\subsection{Sites and traffic}

One site was located in the Chamonix valley (Fig. 1). This valley is $23 \mathrm{~km}$ in length, closed at its lower end by a narrow gorge (the Cluse pass) and at the upper end by the Col des Montets (1464 $\mathrm{m}$ a.s.l. (meters above sea level)) leading to Switzerland. The valley is rather narrow (1 to $2 \mathrm{~km}$ on average at the bottom). The elevation of the valley floor is approximately $1000 \mathrm{~m}$ a.s.l. on average, and is surrounded by tall mountains culminating in the summit of Mont Blanc (4807 $\mathrm{m}$ a.s.1.). There are no industrial emissions or waste incinerators in the valley, and the main anthropogenic sources of emissions are vehicular traffic, residential heating (typically fuel or wood-burning stoves), and some agricultural activity. The permanent population of about 12000 is augmented by tourism, which brings in many times that number (on average 100000 person/day in summer, and about 5 million overnight stays per year), mainly for short-term visits. There is only one road supporting all of the traffic into and out of the valley, but many secondary roads spread over the valley floor and the lower slopes. During the closing of the TMB leading to Italy, the traffic at the entrance of the valley (14400 vehicles/day on average) consisted mainly of cars (91\% of the total, $50 \%$ of which were powered by diesel), along with a small number of local trucks (5\%) and tourist buses (1\%). Due to restriction of the access for the heavy duty trucks, the pattern of the traffic was not really different for the few months included in our study after the reopening of the TMB. Natural sources of emissions are limited to forested areas, which are mainly composed of coniferous 
species (95\% of which consists of spruce, larch and fir). Re-suspension of soil dust is limited in winter, as most of the ground surface is covered by snow. The sampling site was located in the downtown area of the Chamonix town $\left(6^{\circ} 52^{\prime} 16^{\prime \prime} \mathrm{E} ; 45^{\circ} 55^{\prime} 26^{\prime \prime} \mathrm{N}\right.$; altitude $1038 \mathrm{~m}$ a.s.1.), about $10 \mathrm{~m}$ from a street. It can be considered a kerbside site.

The second site was located in the Maurienne valley in a residential urban area of Saint Jean de Maurienne $\left(6^{\circ} 21^{\prime} 04^{\prime \prime} \mathrm{E} ; 45^{\circ} 16^{\prime} 34^{\prime \prime} \mathrm{N}\right.$; altitude $555 \mathrm{~m}$ a.s.1.), about $2 \mathrm{~km}$ from both the highway and some large aluminium plants. It can be considered an urban background site. Saint Jean de Maurienne, the main town in the Maurienne Valley, is about $80 \mathrm{~km}$ from Chamonix in a SSW direction. This valley is much longer (about $80 \mathrm{~km}$ in length) and wider (about $3-5 \mathrm{~km}$ on average at the valley floor) than the Chamonix Valley. The surrounding mountains are lower, peaking at $3852 \mathrm{~m}$ a.s.l. with La Grande Casse. The elevation at the mouth of the valley is $330 \mathrm{~m}$ a.s.l. and increases to $2081 \mathrm{~m}$ a.s.l. at the end of the valley (the Col du Mont Cenis, leading to Italy). The topography of the Maurienne Valley is more complex than that of Chamonix, and includes many tributary valleys and several narrow gorges and sharp bends. The $30 \mathrm{~km}$ of the lower valley up to the town of Saint Jean de Maurienne support several heavy industries, including steel transformation, and aluminium and phosphorus production. Other anthropogenic emissions are linked to traffic. Most traffic (95\% of the trucks and $55 \%$ of the cars) is found on the $50 \mathrm{~km}$ of highway leading from the valley mouth up to the town of Modane, the location of the entrance of the "Tunnel du Fréjus" leading to Italy. The traffic through the valley during the closure of the TMB averaged about 11500 vehicles/day at Saint Jean de Maurienne, with $38 \%$ consisting of heavy-duty diesel trucks. The valley also supports agricultural activities, and some large forested areas, of which $60 \%$ consists of deciduous species (beech and chestnut) and the remaining $40 \%$ being occupied by coniferous trees (spruce). The total population of the valley is represented by about 45000 inhabitants, most of whom are concentrated in the lower $40 \mathrm{~km}$. Tourism is not as important as in Chamonix, but it results in about 4.2 million overnight stays per year on average, mostly during the winter season and in the upper part of the valley, where several ski resorts are located. Emissions inventories were conducted for each valleys for $\mathrm{CO}$, VOC's, $\mathrm{NO}_{\mathrm{x}}, \mathrm{SO}_{2}, \mathrm{CH}_{4}$, and TSP (Total Suspended Particles) (Brulfert et al., 2005b).

\subsection{Sampling and processing}

Both sites are permanent stations maintained by the local Air Quality Agency, l'Air de L'Ain et des Pays de Savoie. Continuous measurements at the stations conducted on a 15-min basis included $\mathrm{NO}_{\mathrm{x}}$ (Environnement $\mathrm{SA}, \mathrm{AC} 31 \mathrm{M}$ ), ozone (Environnement SA, O341M), $\mathrm{SO}_{2}$ (Environnement SA, AS21M), and PM 10 (TEOM1400, R and P). The TEOMs were heated at $50^{\circ} \mathrm{C}$. Air intakes for all of these instruments
Table 1. Sampling dates, and statistics on sampling at both sites.

\begin{tabular}{lcc}
\hline & Chamonix & $\begin{array}{c}\text { Saint Jean } \\
\text { de Maurienne }\end{array}$ \\
\hline Date start & 21 Feb. 2001 & 10 Feb. 2001 \\
Date stop & 3 July 2004 & 52 June 2004 \\
Number of days & 862 & 864 \\
Number of valid samples & 785 & 798 \\
\% of valid samples & 91.1 & 92.4 \\
Number of field blanks & 108 & 113 \\
Number of EC/OC data & 763 & 788 \\
Number of WSOC data & 104 & 277 \\
Number of OA and $\mathrm{K}^{+}$data & 537 & 777 \\
\hline
\end{tabular}

were located about $4 \mathrm{~m}$ above ground on the roofs of the stations.

For this program, we added automatic aerosol sampling with ACCU samplers ( $R$ and $P$ ) on the by-pass flow of the TEOMs. These samplers where kept in a non-heated shelter close to outside temperature. All of the tubing of the ACCU systems was replaced with Teflon-coated lines. We used stainless-steel filter holders with a conical shape to insure homogeneous deposit on the filters. Sampling was conducted on a daily basis, from midnight to midnight (local time), at a flow rate of $0.85 \mathrm{~m}^{3} \mathrm{~h}^{-1}$ (face velocity of $21 \mathrm{~cm} . \mathrm{s}^{-1}$ ). The samplers were serviced once a week, with the collection of 7 samples and one field blank. We used QMA Whatman filters. These were pre-washed for 3 days in 3 successive bathes of Milli-Q water for lowering blanks for ionic species. After drying at $60^{\circ} \mathrm{C}$, they were fired for $1 \mathrm{~h}$ at $800^{\circ} \mathrm{C}$ to lower the blank levels for EC and OC. These filters were kept and transported to the field in packs of 20 in leak-proof glass jars before sampling. After sampling, exposed filters were downloaded directly in the field and stored at $-5^{\circ} \mathrm{C}$ in individual petri slides wrapped in aluminium foil in sealed bags, until the analysis. All handling procedures were designed to reduce potential contaminations.

Sampling was conducted between 21 February 2001 and 3 July 2003 in Chamonix, and between 10 February 2001 and 25 June 2003 in Saint Jean de Maurienne. The number of samples and field blanks are presented in Table 1. While the data series are not totally continuous, the numbers of samples are sufficiently high to give a very good representation of the variability of the concentrations over the sampling periods.

\subsection{Analysis for EC and OC}

Samples were analyzed for EC and OC using the ThermoOptical Transmission (TOT) method on a Sunset Lab analyzer (Birch and Cary, 1996). We used temperatures up to $870^{\circ} \mathrm{C}$ for the analysis of $\mathrm{OC}$ in $100 \% \mathrm{He}$, and up to $900^{\circ} \mathrm{C}$ for the analysis of $\mathrm{EC}$ in $98 \% \mathrm{He}+2 \% \mathrm{O}_{2}$ (Jaffrezo et al., 2005 $\mathrm{b}^{1}$ ). Automatic split time was always used for the 


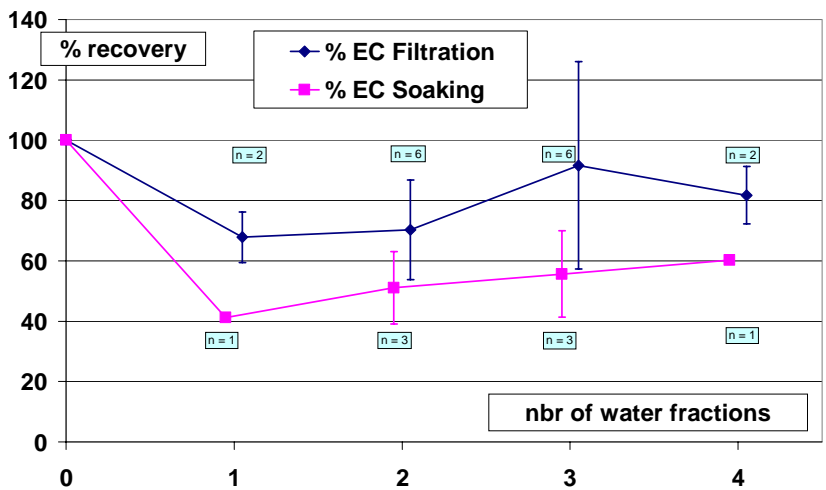

Fig. 2. Recovery of EC after washing with filtration and soaking methods, according to the number of water fractions $(10 \mathrm{ml}$ each) used for the washing. $\mathrm{n}$ is the number of duplicates and the error bar for each point represents \pm 1 standard deviation of the measurements.

distinction between EC and pyrolysed OC, except for blank samples, where it was manually corrected when needed. The transit time between the front oven and the FID detector was optimized and adjusted at $13 \mathrm{~s}$. We analyzed a fraction of $1.5 \mathrm{~cm}^{2}$ from each sample, without any preparation. A subset of samples (approximately 5\% of the overall set, for various sample loadings) was analyzed 3 times to check for the even repartition of particles on the filters and the accuracy of this sub-sampling method for the determination of atmospheric concentration. This test indicated a really good reproducibility of the deposition, with the variability of the results being within $3 \%$.

The arithmetic average of the concentrations of the field blanks was taken into account for the calculation of atmospheric concentrations. Field-blank concentrations (equivalent to concentrations of $\mathrm{OC}=0.45 \pm 0.27 \mu \mathrm{g} \mathrm{C} / \mathrm{m}^{3}$ and $\mathrm{EC}=0.05 \pm 0.06 \mu \mathrm{g} \mathrm{C} / \mathrm{m}^{3}$ for a sample of $20 \mathrm{~m}^{3}$ of air) account for 6.6 and $4.4 \%$ of the average atmospheric concentrations in summer for OC and EC, respectively (Aymoz, 2005). More than 760 daily concentrations for EC and OC were determined for each site (Table 1).

\subsection{Extraction procedures for the determination of WSOC}

We first tested two extraction procedures (named the soaking and filtration methods in the following) aimed at removing the soluble fraction of OC from samples in order to subsequently analyze the remaining insoluble fraction on the filters with the TOT method. Some of the studies referenced in Table 3 use comparable methods. Our tests were performed on real samples collected on the roof of a building in Grenoble, in conditions comparable to those of actual POVA samples. The soaking method consists of the immersion of the filter in $n(n=1$ to 4$)$ successive bathes of $10 \mathrm{ml}$ of Elga ${ }^{\circledR}$ water for $10 \mathrm{~min}$ each. The filtration method consists of the filtration at a low flow rate (with the water sitting for $10 \mathrm{~min}$ prior

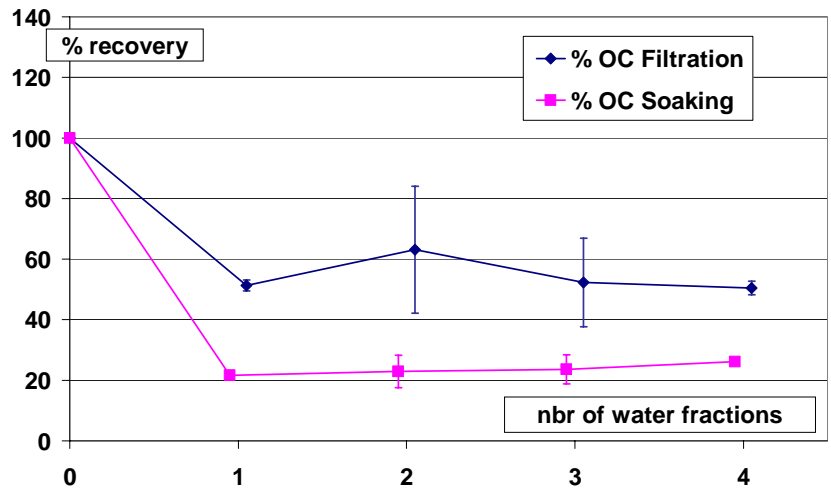

Fig. 3. Recovery of OC after washing with filtration and soaking methods, according to the number of water fractions ( $10 \mathrm{ml}$ each) used for the washing. The number of duplicates is the same as for EC (Fig. 2) and the error bar for each point represents \pm 1 standard deviation of the measurements.

the filtration) of $\mathrm{n}$ ( $\mathrm{n}=1$ to 4 ) successive bathes of $10 \mathrm{ml}$ of Elga ${ }^{\circledR}$ water through the sample held in a Millipore ${ }^{\circledR}$ filtration device. A final step of both methods included drying of the sample in a glove box in a nitrogen atmosphere before the analysis of the filters with the TOT method, following the protocol mentioned above (Sect. 2.3). The procedures were duplicated a number of times, depending on the number of water fractions and method. Figures 2 and 3 present the average percentage of recovery of EC and OC for both methods, respectively, in relation to the number of water fractions used. Results show that the samples are losing EC (about 22 and $48 \%$ by mass on average for the filtration and soaking methods, respectively) as a consequence of the first water fraction, with no further statistically significant changes in EC according to the number of water fractions. As EC is insoluble by definition, removal of these fractions most probably takes place by mechanical processes, with the likely candidates being resuspension in the case of soaking and entrainment in the case of washing. Another hypothesis would be the loss or the change of properties of material that appears as EC during the TOT analysis. In these conditions, the results obtained for OC (decreases of about 56 and $74 \%$ on average for the filtration and soaking methods, respectively) are difficult to interpret in terms of removal of the soluble fraction only (Fig. 3). These methods were subsequently abandoned.

We finally used a method with the direct analysis of the soluble OC in the liquid phase (see below). Single fragments (i.e. portions of $18 \mathrm{~mm}$ in diameter) of $\mathrm{n}$ ( $\mathrm{n}=1$ to 3 , depending on the OC concentrations) successive initial daily samples were soaked together in an airtight glass bottle in $17 \mathrm{ml}$ of Elga ${ }^{\circledR}$ water for 40 min with some manual shaking. The extract was then filtered just before the analysis using Acrodisc filters (Pall Gelmann) with a porosity of $0.2 \mu \mathrm{m}$. 
Table 2. Average detection limits and fraction of samples below detection limit for potassium and the dicarboxylic acids measured in this study.

\begin{tabular}{llccc}
\hline & & Detection limit $\left(\mathrm{ng} / \mathrm{m}^{-3}\right)$ & $\%$ sples $<$ dl (Chamonix) & $\%$ sples $<$ dl (Saint Jean) \\
\hline Potassium & $\mathrm{K}^{+}$ & 12.0 & 6 & 0 \\
Oxalate & $\mathrm{C}_{2} \mathrm{O}_{4}^{2-}$ & 2.4 & 0 & 0 \\
Malonate & $\mathrm{CH}_{2} \mathrm{C}_{2} \mathrm{O}_{4}^{2-}$ & $<1$ & 22 & 14 \\
Succinate & $\left(\mathrm{CH}_{2}\right)_{2} \mathrm{C}_{2} \mathrm{O}_{4}^{2-}$ & $<1$ & 0 & 0 \\
Glutarate & $\left(\mathrm{CH}_{2}\right)_{3} \mathrm{C}_{2} \mathrm{O}_{4}^{2-}$ & $<1$ & 8 & 13 \\
Malate & $\mathrm{CH}_{2} \mathrm{CH}(\mathrm{OH}) \mathrm{C}_{2} \mathrm{O}_{4}^{2-}$ & $<1$ & 14 & 6 \\
Tartarate & $(\mathrm{CH}(\mathrm{OH}))_{2} \mathrm{C}_{2} \mathrm{O}_{4}^{2-}$ & $<1$ & 6 & 10
\end{tabular}

\subsection{Analysis of WSOC}

The analyses of WSOC concentrations were performed with a Model 700 TOC analyzer (OI Analytical). The technique is based on the IR detection of the $\mathrm{CO}_{2}$ formed after the hot chemical oxidation of the carbon content of the liquid sample. The sample is first acidified with $200 \mu \mathrm{l}$ of 5\% phosphoric acid to drive off, using a nitrogen flux for $2.5 \mathrm{~min}$, the $\mathrm{CO}_{2}$ formed from the inorganic carbonates. The OC content of the sample is then oxidized after the addition of $1 \mathrm{ml}$ of sodium persulfate $(100 \mathrm{~g} / \mathrm{l})$, and the resulting $\mathrm{CO}_{2}$ is subsequently measured after degassing with the nitrogen flux. We used a volume of the sampling loop of $10 \mathrm{ml}$, the oxidation time was set to $11 \mathrm{~min}$, and the temperature for the oxidation was $100^{\circ} \mathrm{C}$. These analytical conditions were previously tested by Pertuisot (1997).

The calibration was performed daily with 5 fresh synthetic solutions of sucrose $\left(\mathrm{C}_{12} \mathrm{H}_{22} \mathrm{O}_{11}\right)$ covering the full range of the detector (0 to $4.2 \mu \mathrm{g} \mathrm{C} / \mathrm{ml})$. This calibration was very stable from day to day, with a coefficient of variation (standard deviation over mean) of the slope of $1.6 \%(n=17)$. Several tests were performed to evaluate the uncertainty linked with this analysis. The coefficient of variation of 6 analyses of a synthetic solution at a concentration of $2.1 \mu \mathrm{C} / \mathrm{ml}$ was $0.7 \%$. The average coefficient of variation for the analysis of real atmospheric samples (analyses of 3 fragments for each of 3 actual samples) was $1.5 \%$. It is therefore probably safe to say that the overall uncertainty of the analysis with this method is below 5\%. However, it should be mentionned that the acidification step (lowering the $\mathrm{pH}$ close to 2 ) is probably driving off some of the weak acids included in the original samples, like formic and acetic acids. While their exact concentrations are not known, we can estimate that they represent at most a few $\%$ of the total WSOC concentrations, on the basis of the maximum concentrations that can be measured in the particulate phase in urban environments (Meng et al., 1995; Yang et al., 2005).

A series of 45 blanks were analyzed for their WSOC content and were taken into account for the calculation of atmospheric concentrations. Overall, the average blank value rep- resents $7.2 \pm 1.9 \%$ of the average concentration in Saint Jean de Maurienne. This last series was analyzed totally, leading to 277 values of WSOC concentrations because of the accretion of consecutive samples (Table 1). Only 104 values were obtained for the Chamonix series, representing a selection of samples collected mainly during one summer and two winter periods in order to cover the extrema in temperature at this sampling site.

\subsection{Analysis of organic dicarboxylic acids}

The remaining parts of the filter (after extraction of the fractions for EC/OC and WSOC analyses and removal of the outer ring in contact with the filter holder) were analyzed with Ionic Chromatography (IC) for the determination of a whole suite of anionic and cationic species (Jaffrezo et al., $2005 \mathrm{c}^{2}$ ) following the method described in Jaffrezo et al. (1998), Ricard et al. (2002), and Aymoz (2005). In brief, samples were soaked in $10 \mathrm{ml}$ of Milli-Q water for $30 \mathrm{~min}$ in airtight glass bottles. They were then filtered just before the analysis using Acrodisc filters (Pall Gelmann) with a porosity of $0.2 \mu \mathrm{m}$. Analysis of cations $\left(\mathrm{NH}_{4}^{+}, \mathrm{K}^{+}, \mathrm{Mg}^{2+}, \mathrm{Ca}^{2+}\right)$ took place with a CS12 column on a Dionex 100 IC. The determination of $\mathrm{Na}^{+}$was prevented by the high concentration remaining in the matrix of the quartz filters. Analysis of inorganic anions $\left(\mathrm{Cl}^{-}, \mathrm{NO}_{3}^{-}, \mathrm{SO}_{4}^{2-}\right)$ and dicarboxylic acids (DCA) (oxalate, glutarate, malonate, succinate, malate, and tartrate) took place on an AS11 column on a Dionex 500 analyzer. Table 2 presents the detection limits for these organic acids under the conditions of our analysis. We will only present results concerning the potassium concentration, as well as concentrations for the sum of all measured DCA. The evolution of the concentrations for the individual ionic species are discussed in Jaffrezo et al. (2005c) ${ }^{2}$. The full suite of the daily samples was analyzed for the series from Saint Jean de Maurienne, while only 536 samples were processed for the Chamonix series (Table 1). 
Table 3. WSOC concentrations and mass fractions in the literature. N: number of samples. WSOC fraction of OC, except when noted. References 1: Sempere and Kawamura (1994), 2: Zappoli et al. (1999), 3: Decesari et al. (2001), 4: Krivacsy et al. (2001), 5: Kiss et al. (2002), 6 : Sullivan et al. (2004), 7: Mader et al. (2004), 8: Yang et al. (2005), 9: Ruellan and Cachier (2001), 10: this study, with winter as DJF, etc., *: continuous measurements.

\begin{tabular}{|c|c|c|c|c|c|}
\hline Site & Dates & $\mathrm{N}$ & WSOC $\left(\mu \mathrm{g} / \mathrm{m}^{3}\right)$ & WSOC fraction (\%) & Ref \\
\hline \multirow[t]{2}{*}{ Tokyo (urban) } & Winter 1992 & 2 & $3.2-3.4$ & $28-32 \%$ of $\mathrm{TC}$ & \multirow[t]{2}{*}{1} \\
\hline & Summer 1992 & 2 & $21.3-23.2$ & $32-55 \%$ of $\mathrm{TC}$ & \\
\hline Sweden (rural) & June/July 1996 & 5 & 1.7 & 77 & \\
\hline K-Puszta (rural) & July/August 1996 & 5 & 2.4 & 48 & 2 \\
\hline Italy (urban) & September 96 & 6 & 4.0 & 65 & \\
\hline \multirow[t]{6}{*}{ Pô Valley (rural) } & Jan./Feb. 1998 & 9 & 7.1 & 47 & \multirow[t]{6}{*}{3} \\
\hline & March/April 1998 & 10 & 2.3 & 49 & \\
\hline & May/Sep. 1998 & 9 & 1.4 & 50 & \\
\hline & Oct./Nov. 1998 & 4 & 3.4 & 47 & \\
\hline & Oct./Feb. 1998-1999 & 4 & 5.7 & 38 & \\
\hline & March/April 1999 & 4 & 2.4 & 38 & \\
\hline Jungfraujoch (altitude) & Summer 1998 & 8 & 0.63 & 60 & \multirow{2}{*}{4} \\
\hline K-Puszta (rural) & Summer 1998 & 22 & 4.8 & 63 & \\
\hline K-Puszta (rural) & Jan.-Sep. 2000 & 42 & $2.0-8.25$ & $66 \%$ of $\mathrm{TC}$ & 5 \\
\hline \multirow[t]{3}{*}{ St Louis (urban) } & June 2003 & $*$ & 2.87 & 64 & \multirow[t]{3}{*}{6} \\
\hline & Aug. 2003 & & 2.40 & 61 & \\
\hline & Oct. 2003 & & 1.33 & 31 & \\
\hline ACE-Asia & Spring 01 & 6 & $0.5-7.2$ & $32 \pm 15$ of $\mathrm{TC}$ & 7 \\
\hline Nanjing, China & Feb./Sep. 2001 & 36 & $1.0-14.5$ & $36(17-44 \%)$ & 8 \\
\hline Paris (kerb side) & Aug.-Oct. 1997 & 4 & 4.4 & 12.4 & 9 \\
\hline \multirow{6}{*}{$\begin{array}{l}\text { Chamonix } \\
\text { (urban) } \\
\text { Saint Jean } \\
\text { (urban background) }\end{array}$} & Winter & 69 & $8.8 \pm 3.1$ & $54.5 \pm 6.0$ & \multirow{6}{*}{10} \\
\hline & Summer & 26 & $5.6 \pm 1.0$ & $75.9 \pm 5.9$ & \\
\hline & Winter & 78 & $5.8 \pm 2.4$ & $56.6 \pm 10.0$ & \\
\hline & Spring & 93 & $3.9 \pm 0.8$ & $76.0 \pm 5.7$ & \\
\hline & Summer & 42 & $4.6 \pm 1.0$ & $77.0 \pm 8.5$ & \\
\hline & Fall & 64 & $4.7 \pm 1.6$ & $68.8 \pm 9.8$ & \\
\hline
\end{tabular}

\subsection{Final data set}

The final data set for this long-term sampling campaign also includes daily data for $\mathrm{NO}, \mathrm{NO}_{\mathrm{x}}, \mathrm{O}_{3}, \mathrm{SO}_{2}$, and $\mathrm{PM}_{10}$ concentrations, obtained by averaging the 15-min measurements. Furthermore, our investigation includes an analysis of meteorological data obtained from Météo France (temperature, precipitation, wind speed) from the stations in Chamonix and Saint Jean de Maurienne, with hourly measurements averaged to obtain daily values. We also obtained traffic data from regional administrations and highway companies for the sites of Tunnel des Chavants (at the lower entrance of the Chamonix valley) and Saint Michel de Maurienne $(10 \mathrm{~km}$ upward of Saint Jean de Maurienne). These are daily data sets, with separate counts for individual cars and trucks. Finally, the data pool also includes daily concentrations for many VOC species, sampled in parallel to $\mathrm{PM}_{10}$ with automatic systems during the first year of the campaign (Colomb, 2002). These measurements will not be discussed in this paper. 


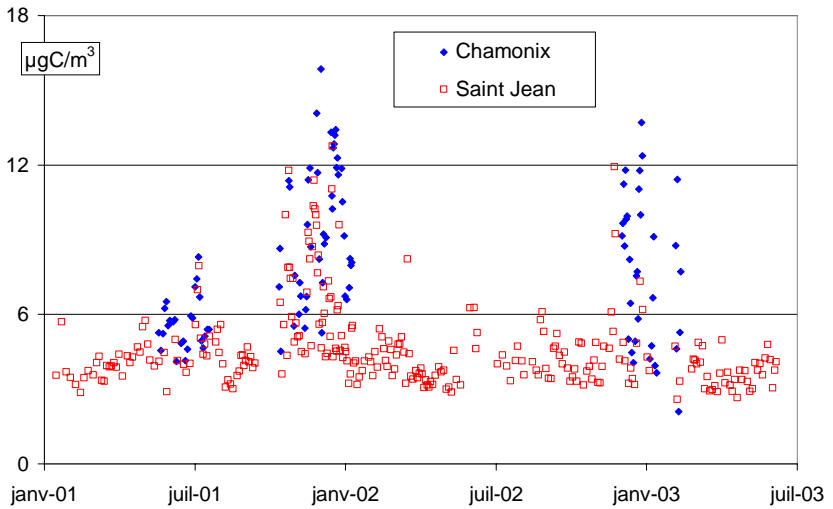

Fig. 4. Evolution of the WSOC concentrations for the two sites for the all sampling period.

\section{Concentrations, mass fractions and seasonal varia- tions of WSOC}

Table 3 presents a comparison of concentrations and WSOC fractions derived from most of the studies available in the literature. With the exception of much higher concentrations in Tokyo (Sempere and Kawamura, 1994) and considerably lower concentrations at the high-altitude site of Jungfraujoch (Kryvacsy et al., 2001), all other concentrations (including our data) are in the same range. However, our data indicates that concentrations of WSOC well above $10 \mu \mathrm{g} \mathrm{C} \mathrm{m}^{-3}$ can be measured in winter conditions in these urban areas, close to the emission sources (Fig. 4). This is much higher than the concentrations obtained in "warm" conditions $\left(\mathrm{T}>15^{\circ} \mathrm{C}\right)$, which are generally considered favourable for the formation of WSOC (Fig. 5). It should be noted that these data are, to the best of our knowledge, some of the first ones to include measurements at temperatures below freezing. We will not discuss the seasonal evolution of WSOC concentrations (Fig. 4), which is strongly dependant upon atmospheric dynamics and local dispersion conditions. A presentation of factors influencing $\mathrm{OC}$ concentrations is presented elsewhere (Aymoz, 2005; Jaffrezo et al., 2005b ${ }^{1}$ ). However, potential sources of WSOC will be discussed below (see Sect. 4).

Figure 6 is presenting the correlations between WSOC and $\mathrm{OC}$ for both series. The regressions are excellent, and lead to very close slopes for the two series, despite the differencies in the location (kerbside for Chamonix, urban background for Saint Jean) and in the emission sources influencing each of the sampling sites (see Sect. 2.1). However, these plots indicate some remaining variability in the relation between OC and WSOC, and it is worth exploring the caracteristics of the evolution of the WSOC fraction.

Average data for WSOC fractions range from a low of $12 \%$ (next to a highway in Paris; Ruellan and Cachier, 2001) up to $80 \%$ for a rural area in Sweden during summer (Zappoli et al., 1999) (Table 3). There is some tendency for lower values to be associated with urban areas, particularly in winter, and

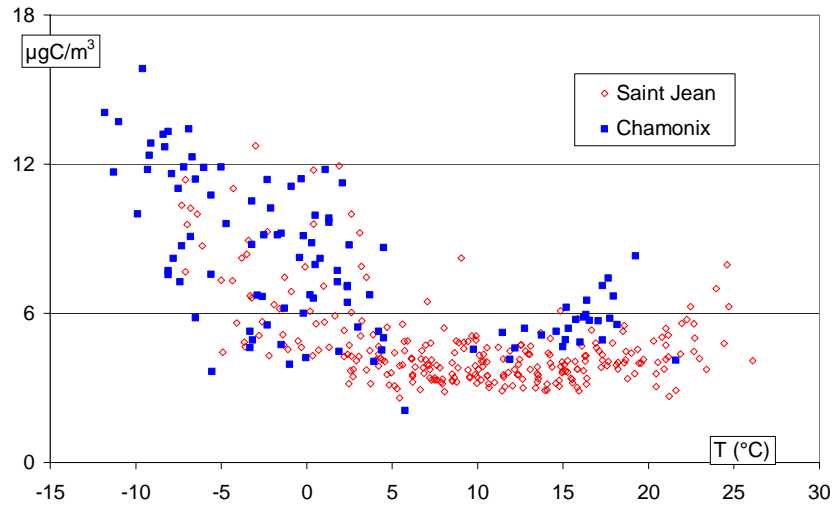

Fig. 5. Evolution of the WSOC concentrations according to the temperature for the two sites.

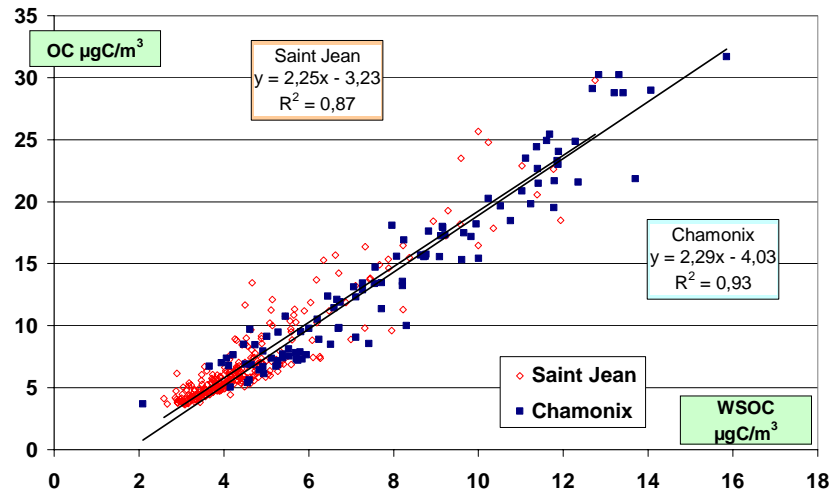

Fig. 6. Correlation between WSOC and OC for the two sites.

for higher values to occur in rural areas, especially in summer. This is more or less consistent with the hypothesis of WSOC consisting of a large fraction of secondary (oxidized and more soluble) organic species. However, these data were obtained using very different protocols and are hardly comparable. No clear seasonal pattern for the evolution of the WSOC fraction has emerged so far from the only consistent data set derived from samples obtained in all seasons (Decesari et al., 2001). Conversly, our data largely confirms such a trend, with lower average values at both sites in winter compared to other seasons (Table 3). Furthermore, these average values are nearly identical for the two sites during both summer and winter, despite their different characteristics.

Figure 7 presents all measurements of the WSOC fraction obtained in this study. First, it confirms that the average results are comparable at the two sites, despite their specificities. This is quantified in Table 4, with the average values of this ratios calculated for the periods with parallel samples. Second, Fig. 7 shows a clear seasonal cycle for the Maurienne series, with the discontinuous series from Chamonix being indicative of a comparable behaviour. One can see minima during both winters (2002 and 2003) for the two sites. While the values during the 3 summer periods are 
Table 4. Average values of the ratio WSOC/OC at the two sites during the 3 periods with parallel sampling.

\begin{tabular}{ccccc}
\hline & & & Chamonix & Saint Jean \\
\hline Winter 2001/2002 & 5 Nov. 2001 & 31 Jan. 2002 & $0.53 \pm 0.07$ & $0.52 \pm 0.08$ \\
Summer 2002 & 15 June 2002 & 14 Aug. 2002 & $0.76 \pm 0.06$ & $0.74 \pm 0.10$ \\
Winter 2002/2003 & 20 Dec. 2002 & 31 Jan. 2003 & $0.56 \pm 0.04$ & $0.66 \pm 0.07$ \\
\hline
\end{tabular}

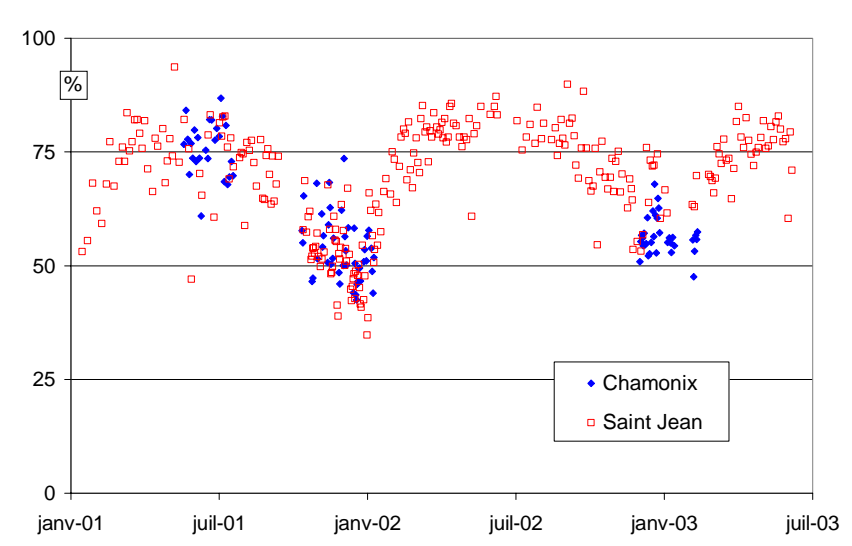

Fig. 7. Evolution of the WSOC fraction for the overall sampling period at the two sites.

rather similar between each other (averages in the range 75$80 \%$ ), the minimum values during the winters are different, reaching (for both sites) $40-45 \%$ for the winter of 2002, but remaining above $50 \%$ during the winter of 2003 . This suggests a possible correlation with changes in temperature, with the former period being colder than the later one (respectively $-6.3^{\circ} \mathrm{C}$ and $-1.4^{\circ} \mathrm{C}$, for the periods 1 December- 15 January in both years in Chamonix).

All of these observations are confirmed in Fig. 8, which shows the evolution of the WSOC fraction in relation with temperature for both sites, together with the moving average (and standard deviation) for each $2^{\circ} \mathrm{C}$ increment. A clear pattern of change emerges, with the average WSOC fraction being stable at $54.8 \pm 7.7 \%$ and $75.9 \pm 6.3 \%$ for temperatures below $3^{\circ} \mathrm{C}$ (in the range -10 to $+3^{\circ} \mathrm{C}$ ) and above $12^{\circ} \mathrm{C}$ (in the range 12 to $24^{\circ} \mathrm{C}$ ), respectively. There is a constant increase in the WSOC fraction between these ranges. These observations indicate that, on average, there are processes that prevent on the one hand WSOC fractions higher than $80 \%$, even for so-called favourable oxidation conditions, and on the other hand WSOC fractions lower than $40 \%$ for conditions that do not favour the oxidation of primary OC.

However, the dispersion is still rather high (average coefficient of variation about $11.1 \%$ for all of the $2^{\circ} \mathrm{C}$ intervals), and indicates that temperature (taken as a gauge of oxidation conditions) is not the only factor affecting the observed patterns. It is therefore interesting to try to relate these changes with other indicators of oxidation or with tracers of sources.

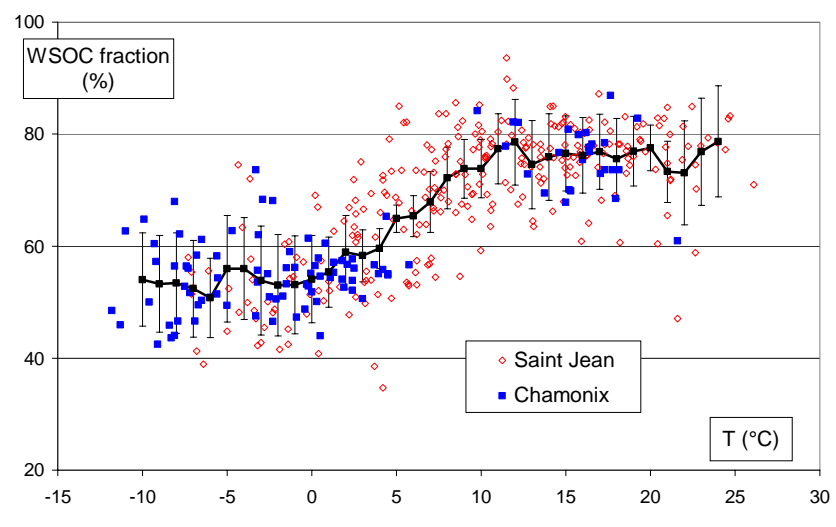

Fig. 8. Evolution of the WSOC fractions according to the temperature for the two sites.

\section{Relation between WSOC, ozone, organic diacids and potassium}

The evolution of the WSOC fraction has already been positively related to ozone concentrations in some studies (Sullivan et al., 2004), indicating a degree of dependency between processes that lead to the formation of oxidized species in the gas and particulate phases. However, it has been shown that such a relation does not hold in all environmental conditions, and no further gain was made in the understanding of the connection between the processes (Sullivan et al., 2004). In our case, there are also some degrees of co-variation between ozone concentrations and the WSOC fractions at both sites, but the relations are not strong:

WSOC fraction $(\%)=0.28 \times\left[\right.$ ozone $\left.\quad\left(\mu \mathrm{g} \mathrm{m}^{-3}\right)\right]+56.9$; $r^{2}=0.45 ; n=277$ in Saint Jean

WSOC fraction $(\%)=0.32 \times\left[\right.$ ozone $\left.\quad\left(\mu \mathrm{g} \mathrm{m}^{-3}\right)\right]+51.3$; $\mathrm{r}^{2}=0.51 ; \mathrm{n}=104$ in Chamonix.

However, the correlations between WSOC and ozone concentrations are much lower:

WSOC $\left(\mu \mathrm{g} \mathrm{C} \mathrm{m}^{-3}\right)=-0.026 \times\left[\right.$ ozone $\left.\quad\left(\mu \mathrm{g} \mathrm{m}^{-3}\right)\right]+5.81$; $\mathrm{r}^{2}=0.18 ; \mathrm{n}=277$ in Saint Jean

WSOC $\left(\mu \mathrm{g} \mathrm{C} \mathrm{m}^{-3}\right)=-0.065 \times\left[\right.$ ozone $\left.\quad\left(\mu \mathrm{g} \mathrm{m}^{-3}\right)\right]+9.65$; $\mathrm{r}^{2}=0.29 ; \mathrm{n}=104$ in Chamonix.

The absence of a correlation can reflect the influence of many processes, such as differences in oxidation and removal 


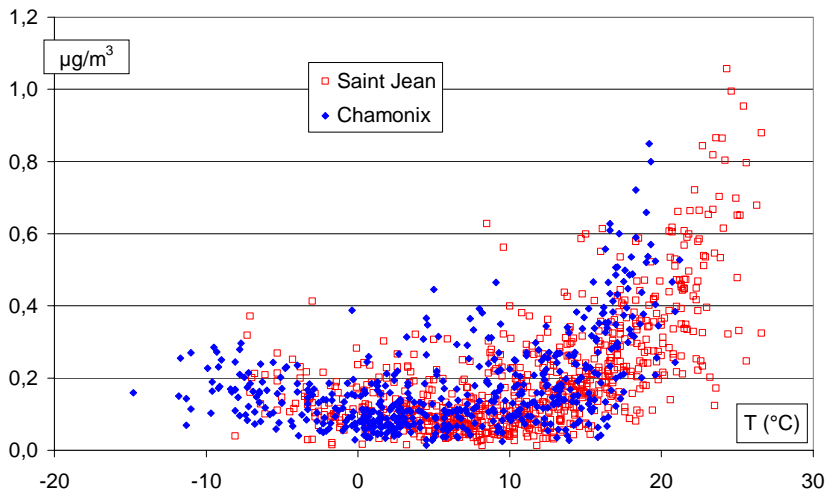

Fig. 9. Evolution of the sum of the concentrations of the dicarboxylic acids (DCA) measured, according to the temperature for the two sites.

processes, their time scales, temperature dependence, or differences in the concentrations of primary species. Indeed, a more interesting approach concerns the comparison of concentrations of WSOC with concentrations of species of known secondary origin in the particulate phase. This is the case for dicarboxylic acids (DCA), which are generally regarded as end products of the oxidation of primary species, even if primary sources appear to be present in urban atmospheres (Chebbi and Carlier, 1996). The most likely oxidation pathways for the production of DCA are probably in aqueous phase (hydrated particles or cloud droplets) after an initial gas phase oxidation of primary compounds (Ervens et al., 2004), since direct production in the gas phase seems unlikely (Aumont et al., 2000).

Figure 9 presents the change of concentrations of the sum of DCA measured in our samples (expressed in $\mu \mathrm{g} / \mathrm{m}^{3}$ ) in relation to temperature. It shows a large and continuous increase of the concentrations for warmer temperatures, and is consistent with a secondary production by oxidation. The concentrations do not reach a plateau for the warmer temperatures, an indication that the production of these species with low vapour pressures is not the limiting factor explaining the maximum ratio at $80 \%$ for the WSOC fraction (Fig. 8). The concentrations are still significant for cooler temperatures, possibly indicating primary production or some extent of secondary formation. Indeed, the behaviour at sub-freezing temperatures is not the same for all species investigated (Aymoz, 2005), with some species (tartrate, malate) showing nearzero concentrations while others (oxalate) exhibit significant concentrations.

Figure 10 presents the mass fraction of WSOC represented by the measured DCA (expressed in $\mu \mathrm{g} \mathrm{C} / \mathrm{m}^{3}$ ) in relation to temperature. Again, we observe a large and continuous increase with increasing temperature which does not show any sign of reaching a limitation. This mass fraction reaches a level of about $4 \%$, and is in the range discussed by Saxena and Hildemann (1996) for observations made in urban sites. This mass fraction is much lower at low temperatures, and

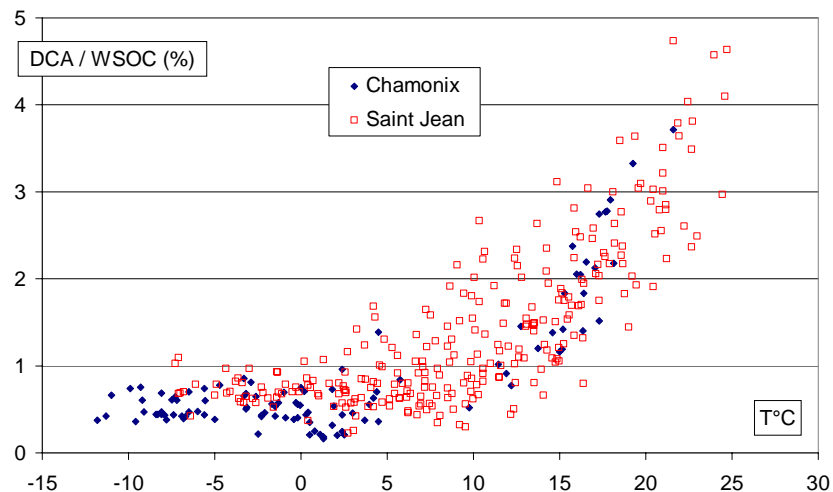

Fig. 10. DCA fraction of the WSOC according to the temperature at the two sites.

the measured DCA never account for more than $1 \%$ of the WSOC concentration for $\mathrm{T}^{\circ} \mathrm{C}<4^{\circ} \mathrm{C}$.

Indeed, Figs. 11 and 12 show that very different links exist between WSOC and DCA on each side of a threshold temperature, with large increases of DCA concentrations occurring with moderate increases for WSOC concentrations for the higher temperatures. Conversely, the increase of DCA is only minor when large increases in WSOC concentrations occur at the lower temperatures. This clearly indicates two regimes for the formation of WSOC: one being closely related to oxidation processes producing DCA (at warmer temperatures), and another (at lower temperatures) being more loosely dependent upon the formation of these secondary species.

The slopes and intercepts of the regressions (Figs. 11 and 12) are similar for the two sites particularly in summer, and indicate that the processes may be the same in the two valleys. However, there is a difference of $4^{\circ} \mathrm{C}$ in the threshold temperature between the two sites, corresponding to the difference in the average daily temperatures at the sites:

$\mathrm{T}^{\circ} \mathrm{C}(\mathrm{CHX})=0.99 \times \mathrm{T}^{\circ} \mathrm{C}(\mathrm{STJ})-4.3\left(\mathrm{r}^{2}=0.96 ; \mathrm{n}=2145 ; 18\right.$ July 97 to 01 June 03 ).

A possible hypothesis to explain this difference is that the link between WSOC and DCA for the warmer temperature range results from oxidation reactions that take place at similar temperatures at places further away from the sampling sites in the plains of the foothills, with the aerosols being subsequently transported into the valleys (with the temperature at each receptor site being dependent on its altitude, among others factors). This hypothesis could be supported by the large impact of imported air-masses demonstrated for the modulation of the ozone concentrations in the valleys in summer (Brulfert, 2004 ; Brulfert et al., 2005a). Furthermore, this hypothesis could explain the same shift of $4^{\circ} \mathrm{C}$ that is also seen in Figs. 5 and 9 for the increases in the concentrations of WSOC and DCA in the warmer temperature ranges. This implies that a large share of the summer $\mathrm{PM}_{10}$ particles (at least for the secondary species) at both sites could result 


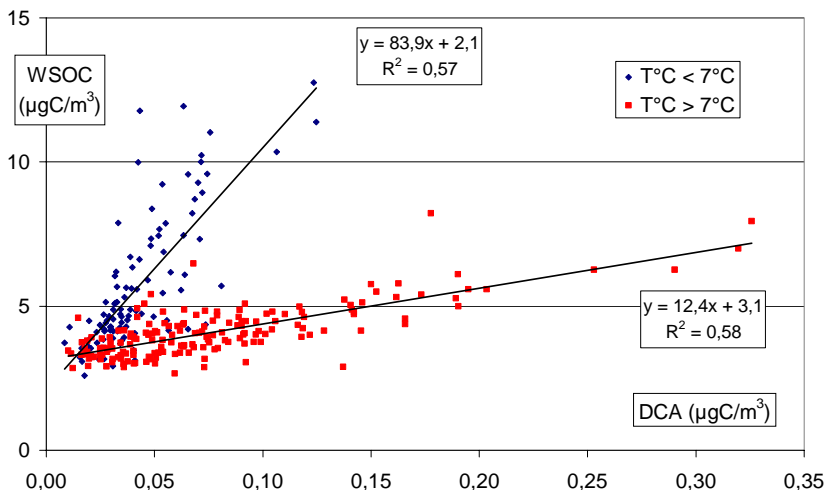

Fig. 11. Dicarboxylic acids and WSOC concentrations according to the temperature in Saint Jean de Maurienne.

from transport. All of this remains to be fully demonstrated with the determination of the fractions of OC, WSOC, and DCA produced locally vs transported from surrounding areas.

The case involving cold temperatures is more complex, exhibiting a weaker correlation between DCA and WSOC (all expressed in $\mu \mathrm{g} \mathrm{C} / \mathrm{m}^{3}$ ) when considering the combined data set:

WSOC $=13.4 \times \mathrm{DCA}+3.27\left(\mathrm{r}^{2}=0.48\right)$ for "warm conditions" $(\mathrm{n}=206)$

WSOC $=87.0 \times \mathrm{DCA}+3.32\left(\mathrm{r}^{2}=0.33\right)$ for "cold conditions" $(\mathrm{n}=173)$,

("warm" and "cold" conditions being defined according to the threshold temperatures presented in Figs. 11 and 12). This may reflect the impact of several processes, or of different processes in each valley, on the production of WSOC in winter. It should be remembered that the characteristics of aerosol at our two sites are more strongly influenced by local conditions (primary emissions, meteorology) in winter than in summer periods (Aymoz, 2005). At least three nonexclusive hypotheses can be proposed to explain both the weak link between DCA and WSOC, and the large WSOC fraction during winter: i) direct emissions of soluble species, ii) oxidation pathways different between summer and winter periods, and iii) changes in the gas/particle repartition for semi-volatile species.

The strong influence of temperature on the repartition of semi-volatile species between gas and particulate phases (described by the coefficient $K_{p}$ ) is well known (Pankow, 1994), and was verified in our case for some PAH species (Marchand, 2003). It has been shown, for example, that $K_{p}$ can change by nearly 2 orders of magnitude between $21^{\circ} \mathrm{C}$ and $-3^{\circ} \mathrm{C}$ for some semi-volatile species (Leaitch et al., 1999), a change that is dependent upon the enthalpy of vaporization of the species (Tsigaridis and Kanakidou, 2003; Pun et al., 2003). Such a response has been reported for soluble aldehydes (Saxena and Hildemann, 1996). There-

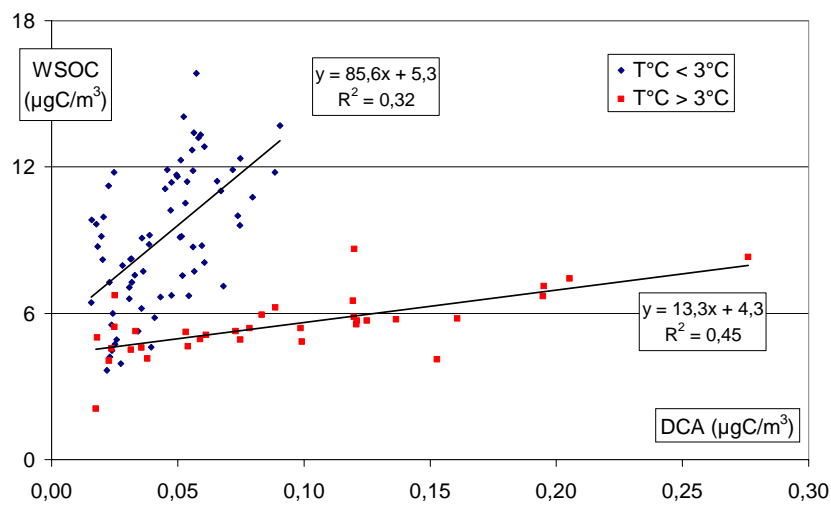

Fig. 12. Dicarboxylic acids and WSOC concentrations according to the temperature in Chamonix.

fore, larger concentrations of such species (both primary and secondary) could be transferred in the particulate phase during winter. Additionally, partitioning for each species is dependent upon the composition of the aerosol that is already condensed, with $K_{p}$ greatly increasing with the affinity between the condensed and condensable products (Leaitch et al., 1999; Chandramouli et al., 2003). Residential biomass burning is a significant source of OC in winter in the valley (see below), with a large share of the emission products being composed of polar compounds, potentially increasing the condensation of this class of soluble species. However, detailed studies of the relation between the particulate and gaseous phases together with further molecular speciation of OC and WSOC are needed to verify if such a process can have a significant impact on the WSOC fraction of OC at low temperatures.

The oxidation of primary species during winter conditions is also possible, but it is still rather difficult to evaluate its importance in terms of the chemical evolution of OC. Measurements of the size distribution of $\mathrm{OC}$ in winter during POVA (Jaffrezo et al., 2005a) show that a very large fraction of its mass $(61 \pm 2 \%, n=6$ daily samples collected in January 2003) exists in the so-called droplet mode (aerodynamic diameter in the range 0.26 to $1.0 \mu \mathrm{m}$ ), which is generally associated with cloud processing of smaller particles (Blando and Turpin, 2000; Ervens et al., 2004). A much smaller fraction of the OC mass exists in the lower size ranges $(15 \pm 1 \%$, for the same samples) associated with primary emissions, such as those produced from diesel (Kerminen et al., 1997) or wood-smoke emissions (Hays et al., 2004). Oxalate is also measured in the same samples and exists mainly in this droplet mode, albeit with a much lower mass ratio to OC than that found in summer samples. Such a cloud-processing during winter could take place locally in the fog that formed at the top of the low inversion layers during anti-cyclonic conditions. The processes involved in the formation of such a droplet mode at low temperature could lead to a chemical repartition of soluble organic species that differ from those 


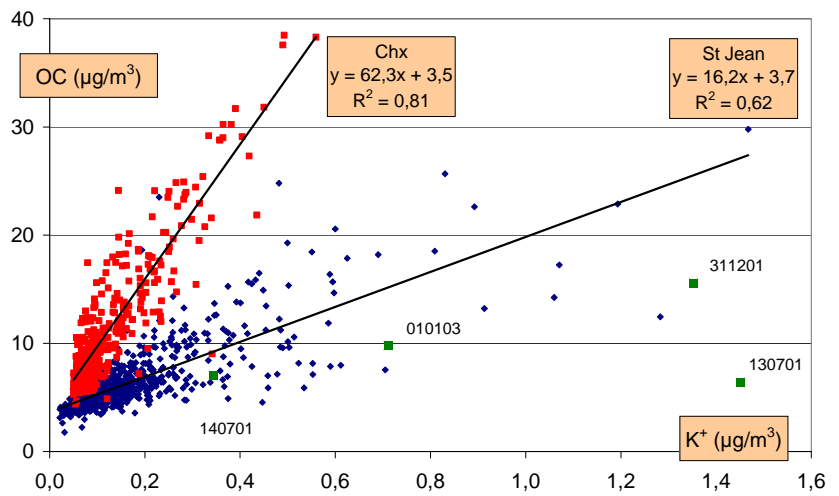

Fig. 13. Potassium and OC concentrations at both sites. The points in the green color (with their date of collection) are not included in the correlations.

of the summer period, and may potentially include aldehydes and other compounds (Blando and Turpin, 2000), as well as polyacidic compounds (Decesari et al., 2001), all of them being soluble. In support of such an hypothesis, polyacidic compounds were present in larger proportions in the winter rather than summer samples in the study of Decesari et al. (2001). However, this hypothesis of a production of soluble OC during cloud processing in the valleys in winter needs to be tested extensively, for example with the comparison of the OC composition of the aerosol during foggy vs. non foggy periods.

Finally, we can try to test the hypothesis concerning a change in the sources of OC that would increase WSOC concentrations in winter independently of DCA production. We have several indications that residential wood burning represents a substantial share of the emissions of OC in winter in the valleys (Marchand et al., 2004, 20053 ; Aymoz, 2005), as it can account for up to $60-75 \%$ of the PAH concentrations measured in some areas of the Chamonix valley during this season. It is well known that these emissions include a large proportion of soluble organic species (Mayol-Bracero et al., 2002; Schauer et al., 2001). We can attempt an evaluation of the impact of this source between cold and warm conditions by considering the ratio with soluble potassium, a species also emitted by wood burning. Figure 13 shows the correlation between $\mathrm{OC}$ and $\mathrm{K}^{+}$using the overall data set for the two sites.

Excluding a few points (13 and 14 July 2001, 31 December 2001, and 1 January 2003) that are influenced by fireworks, the correlation for the Chamonix series is high (Fig. 13), while the correlation is lower for samples from the Maurienne Valley. The same observations can be made when considering the correlations between $\mathrm{WSOC}$ and $\mathrm{K}^{+}$:

Chamonix: WSOC $\left(\mu \mathrm{g} \mathrm{C} / \mathrm{m}^{3}\right)=26.7 \times \mathrm{K}^{+} \quad\left(\mu \mathrm{g} / \mathrm{m}^{3}\right)+3.5$

${ }^{3}$ Marchand, N., Aymoz, G., Jaffrezo, J. L., Masclet, P., and Besombes J. L.: Biomass burning indicators in the aerosol of Alpine valleys, Atmos. Chem. Phys. Discuss., in preparation, 2005.
Table 5. Values of the ration $\mathrm{OC} / \mathrm{K}^{+}$at the two sites.

\begin{tabular}{ccccc}
\hline & $\mathrm{OC} / \mathrm{K}^{+}$mean & $\begin{array}{c}\text { Standard } \\
\text { deviation }\end{array}$ & Median & $\mathrm{N}$ \\
\hline Chamonix & & & & \\
$\mathrm{T}<3^{\circ} \mathrm{C}$ & 108.3 & 43.2 & 94.7 & 202 \\
$\mathrm{~T}>3^{\circ} \mathrm{C}$ & 134.3 & 62.4 & 119.5 & 318 \\
& & & & \\
Saint Jean & & & & \\
$\mathrm{T}<7^{\circ} \mathrm{C}$ & 48.1 & 25.2 & 41.6 & 246 \\
$\mathrm{~T}>7^{\circ} \mathrm{C}$ & 51.8 & 13.7 & 47.3 & 526 \\
\hline
\end{tabular}

$\left(\mathrm{r}^{2}=0.82 ; \mathrm{n}=95\right)$

Saint Jean: WSOC $\left(\mu \mathrm{g} \mathrm{C} / \mathrm{m}^{3}\right)=6.8 \times \mathrm{K}^{+} \quad\left(\mu \mathrm{g} / \mathrm{m}^{3}\right)+3.7$ $\left(\mathrm{r}^{2}=0.62 ; \mathrm{n}=277\right)$.

The $\mathrm{OC} / \mathrm{K}^{+}$ratios shown in Table 5 can be compared to the values of 71-85 presented by Khalil and Rasmussen (2003) for measurements in Olympia (WA, USA) under conditions strongly influenced by residential wood burning, or to measurements of direct fireplace emissions performed by Schauer et al. (2001) that yielded ratios of 202 (for pine) and 91 (for oak) for the fine fraction (diameter $<1.8 \mu \mathrm{m}$ ) of the aerosol. In both studies, elemental $\mathrm{K}$ and not $\mathrm{K}^{+}$was measured. Compared to such values, the low ratio observed for Saint Jean may indicate additional sources of potassium, but we cannot propose any candidate at this point in our study. Taking into account all of the uncertainties associated with the measurements of $\mathrm{OC}$, both the ratio $\mathrm{OC} / \mathrm{K}^{+}$and the high correlation between $\mathrm{OC}$ and $\mathrm{K}^{+}$are more suggestive of a significant impact by residential wood burning in the case of Chamonix. It is therefore possible that this emission source influences the WSOC winter concentrations in Chamonix, and could be implicated in the change in the WSOC/DCA ratio between winter and summer observed in this series. However, the small changes of the $\mathrm{OC} / \mathrm{K}^{+}$ratio between winter and summer periods remain unclear (Table 5), and further investigations are needed to substantiate the hypothesis of a change in the WSOC fraction modulated by residential wood-burning emissions in both valleys during winter.

\section{Conclusions}

Concentrations of Water Soluble Organic Carbon and WSOC fraction to $\mathrm{OC}$ were measured at two urban sites in valleys of the French Alps during a period of two and a half years. Concentrations were as high as $10-15 \mu \mathrm{g} \mathrm{C} / \mathrm{m}^{3}$ in winter, but there is a clear seasonal cycle of the WSOC fraction, with minima occurring during winter. This reflects a marked dependency on temperature, with the average WSOC fraction being stable at $54.8 \pm 7.7 \%$ and $75.9 \pm 6.3 \%$ for temperatures in the ranges -10 to $+3^{\circ} \mathrm{C}$ and 12 to $24^{\circ} \mathrm{C}$, respectively. 
Several points are noteworthy in this evolution. First, there are limiting factors that prevent lower mass fractions in the low temperature range and higher mass fractions in the high temperature range. Second, the mass fraction at the lower temperature is rather high, in apparent contradiction with OC being mainly insoluble close to the emission sources. Third, the range of $20 \%$ for the change of the WSOC fraction between these extreme conditions is indeed rather narrow when compared to evaluations of the secondary (and supposedly water soluble) OC fraction proposed in the literature, with most of the published values being in the range 40 to 70\% (Castro et al., 1999; Strader et al., 1999; Na et al., 2004). All of these points deserve further investigation, both in other environmental conditions and in association with other measurements (molecular speciation, evaluation of chemical functional groups, etc.) in the valleys.

A comparison of the evolution of WSOC concentrations with that of dicarboxylic acids (DCA) clearly indicates the influence of two regimes in the formation of WSOC: one at higher temperatures classically linked with the increase of DCA concentrations and associated with oxidation processes, and another one at lower temperatures involving a much lower increase of DCA concentrations. We propose several hypotheses involving processes that could be responsible for the large concentrations of WSOC in the particulate phase at our sites during winter time. None of these hypotheses can be fully validated or dismissed with our supporting data, but the influence of wood burning is a likely candidate. Investigations on the WSOC fraction at low temperatures are needed, for such a temperature range is of the utmost importance for cloud formation.

Acknowledgements. The program POVA was supported by Région Rhône-Alpes, ADEME (Agence pour le Développement et la Maîtrise de l'Energie), METL (Ministère de l'Equipement, des Transports et du Logement), MEDD (Ministère de l'Environnement et du Développement Durable), and Programme Primequal 2. We would like to thank Météo France for providing the meteorological data, and DDE 73, DDE 74, and SFTRF for providing the traffic data. The sampling was superbly maintained during the overall period by the Air Quality Agency "L'Air de l'Ain et des Pays de Savoie" (http://www.atmo-rhonealpes.org/). We would like to thank S. Mongin, D. Gaude, H. Bulté, M. Lelimousin, and C. Delabarde for part of the analyses.

Edited by: R. Hitzenberger

\section{References}

Aumont, B., Madronich, S., Bey, I., and Tyndall, G.: Contribution of secondary VOC to the composition of aqueous atmospheric particles: a modeling approach, J. Atmos. Chem., 35, 59-75, 2000.

Aymoz, G.: Etude de la fraction carbonée de l'aérosol atmosphérique à Chamonix et St Jean de Maurienne: évolutions saisonnières, sources et caractéristiques chimiques, Thèse de l'Université J. Fourier, Grenoble, France, 258pp, available at: http://tel.ccsd.cnrs.fr/documents/archives0/00/00/89/18/ index_fr.html, 2005.

Birch, M. E. and Cary, R. A.: Elemental carbon-based method for monitoring occupational exposures to particulate diesel exhaust, Aerosol. Sci. Technol., 25, 221-241, 1996.

Blando, J.D. and Turpin, B. J.: Secondary organic aerosol formation in cloud and fog droplets: a literature evaluation of plausibility, Atmos. Environ., 34, 1623-1632, 2000.

Brulfert, G.: Modélisation des circulations atmosphériques pour l'étude de la pollution des vallées alpines. Thèse de l'Université J. Fourier, Grenoble, France, 271pp, available at: http://tel.ccsd. cnrs.fr/documents/archives0/00/00/79/82/index_fr.html, 2004.

Brulfert, G., Chemel, C., Chaxel, E., and Chollet, J. P.: Modelling photochemistry in alpine valleys, Atmos. Chem. Phys., 5, 23412355, 2005a,

SRef-ID: 1680-7324/acp/2005-5-2341.

Brulfert, G., Chollet, J. P., Jouve, B., and Villard, H.: Atmospheric emission inventory of the Maurienne valley for an atmospheric numerical model, Sci. Tot. Environ., 349, 232-248, 2005b.

Castro, L. M., Pio, C. A., and Harrison, R. M.: Carbonaceous aerosol in urban and rural European atmospheres: estimation of secondary organic carbon concentrations, Atmos. Environ., 33, 2771-2781, 1999.

Chandramouli, B., Jang, M., and Kamens, R. M.: Gas-particle partitioning of semivolatile organic compounds (SOCs) on mixtures of aerosols in a smog chamber, Environ. Sci. Technol., 37, 41134121, 2003.

Chebbi, A. and Carlier, P.: Carboxylic acids in the troposphere, occurrence, sources and sinks: a review, Atmos. Environ., 30, 4233-4249, 1996.

Colomb, A.: Les composés organiques volatils dans les Vallées Alpines: sources, évolutions et transformations, Thèse de l'Université J. Fourier, Grenoble, France, 346 pp, 2002.

Decesari, S., Facchini, M. C., Matta, E., Lettini, F., Mircea, M., Fuzzi, S., Tagliavini, E., and Putaud, J. P.: Chemical features and seasonal variation of fine aerosol water-soluble organic compounds in the Po Valley, Italy, Atmos. Environ., 35, 3691-3699, 2001.

Dreher, K. L.: Particulate matter physicochemistry and toxicology, in: search of causality: a critical perspective, Inhalation Tox., 12 (supp 3), 45-57, 2000.

Ervens, B., Feingold, G., Frost, G. J., and Kreidenweis, S. M.: A modeling study of aqueous production of dicarboxylic acids: 1 . Chemical pathways and speciated organic mass production, J. Geophys. Res., 109, D15205, doi:10.1029/2003JD004387, 2004.

Hays, M. D., Dean Smith, N., and Dong, Y.: Nature of unresolved complex mixture in size-distributed emissions of residential wood combustion as measured by therma desorptiongas chromatography-mass spectrometry, J. Geophys. Res., 109, D16S04, doi:10.1029/2003JD004051, 2004.

Jaffrezo, J. L., Calas, N., and Boucher, M.: Carboxylic acids measurements with ionic chromatography, Atmos. Environ., 32, 2705-2708, 1998.

Jaffrezo, J. L., Aymoz, G., and Cozic, J.: Size distribution of EC and $\mathrm{OC}$ in Alpine valleys during summer and winter, Atmos. Chem. Phys. Discuss., 5, 3773-3809, 2005a,

SRef-ID: 1680-7375/acpd/2005-5-3773.

Kanakidou, M., Seinfeld, J. H., Pandis, S. N., Barnes, I., et al.: 
Organic aerosol and global climate modelling: a review, Atmos. Chem. Phys., 5, 1053-1123, 2005,

SRef-ID: 1680-7324/acp/2005-5-1053.

Kerminen, V. M., Makela, T. E., Ojanen, C. H., Hillamo, R. E., Vilhunen, J. K., Rantanen, L., Havers, N., Von Bohlen, A., and Klockow, D.: Characterisation of the particulate phase in the exhaust of a diesel car, Environ. Sci. Technol., 31, 1883-1889, 1997.

Khalil, M. A. K. and Rasmussen, R. A.: Tracers of wood smoke, Atmos. Environ., 37, 1211-1222, 2003.

Kiss, G., Varga, B., Galambos, I., and Ganszky, I.: Characterization of water-soluble organic matter isolated from atmospheric fine aerosol, J. Geophys. Res., 107, 8339, doi:10.1029/2001/JD000603, 2002.

Krivácsy, Z., Hoffer, A., Sárvári, Z., Temesi, D., Baltensperger, U., Nyeki, S., Weingartner, E., Kleefeld, S., and Jennings, S. G.: Role of organic and black carbon in the chemical composition of atmospheric aerosol at European background sites, Atmos. Environ., 35, 6231-6244, 2001.

Leaitch, K. B., Kamens, R. M., Strommen, M. R., and Jang, M.: Partitioning of semivolatile organic compounds in the presence of a secondary organic aerosol in a controlled atmosphere, J. Atmos. Chem., 33, 241-264, 1999.

Mader, B. T., Yu, J. Z., Xu, J. H., Li, Q. F., Wu, W. S., Flagan, R. C., and Seinfeld, J. H.: Molecular composition of the water-soluble fraction of atmospheric carbonaceous aerosols collected during ACE-Asia, J. Geophys. Res., 109, D06206, doi:10.1029/2003JD004105, 2004.

Marchand, N.: Etude de la composante organique de l'aérosol atmosphérique : cas de deux vallées alpines (Chamonix et Maurienne) et développement analytique. Thèse de l'Univ. De Savoie, Chambéry, France, 339 pp, available at: http://tel.ccsd.cnrs.fr/ documents/archives0/00/00/35/33/index_fr.html, 2003.

Marchand, N., Besombes, J. L., Chevron, N., Masclet, P., Aymoz, G., and Jaffrezo, J. L.: Polycyclic aromatic hydrocarbons (PAHs) in the atmospheres of two French alpine valleys: sources and temporal patterns, Atmos. Chem. Phys., 4, 1167-1181, 2004,

SRef-ID: 1680-7324/acp/2004-4-1167.

Mayol-Bracero, O., Guyon, P., Graham, B., Roberts, G., Andreae, M. O., Decesari, S., Facchini, M. C., Fuzzi, S., and Artaxo, P.: Water soluble organic compounds in biomass burning aerosols over Amazonia: 2. Apportionment of the chemical composition and importance of the polyacidic fraction, J. Geophys. Res., 107, 8091, doi:10.1029/2001/JD000522, 2002.

Meng, Z., Seinfeld, J. H., and Saxena, P.: Gas/aerosol distribution of formic and acetic acids, Aerosol. Sci. Technol., 23, 561-578, 1995.

Na, K., Sawant, A. A., Song, C., and Cocker III, D. R.: Primary and secondary carbonaceous species in the atmosphere of Western Riverside County, California, Atmos. Environ., 38, 1345-1355, 2004

Pertuisot, M. H.: Transfert du carbone atmosphérique dans les neiges et les pluies, Thèse de doctorat de l'Université de Paris VII, $250 \mathrm{pp}, 1997$.
Pankow, J. F.: An absorption model of gas/particle partitioning of organic compounds in the atmosphere, Atmos. Environ., 28, 185-188, 1994.

Pun, B. K., Wu, S. Y., Seigneur, C., Seinfeld, J. H., Griffin, R. J., and Pandis, S.: Uncertainties in modelling secondary organic aerosols: three-dimensional modeling studies in Nashville/Western Tennessee, Environ. Sci. Technol., 37, 3647 3661, 2003.

Ricard, V., Jaffrezo, J. L., Kerminen, V. M., Hillamo, R. E., Sillanpaa, S., Ruellan, S., Liousse, C., and Cachier, H.: Two years of continuous aerosol measurements in northern Finland, J. Geophys. Res., 107, D11, 101029 , ACH 10, doi:10.1029/2001JD000952, 2002.

Ruellan, S. and Cachier, H.: Characterization of fresh particulate vehicular exhausts near a Paris high flow road, Atmos. Environ., 35, 453-468, 2001.

Saxena, P. and Hildemann, L.: Water-soluble organics in atmospheric particles: A critical review of the literature and application of thermodynamics to identify candidates compounds, J. Atmos. Chem., 24, 57-109, 1996.

Schauer, J. J., Kleeman, M. J., Cass, G. R., and Simoneit, B. R. T.: Measurement of emissions from air pollution sources. 3. C1-C29 organic compounds from fireplace combustion of wood, Environ. Sci. Technol., 35, 1716-1728, 2001.

Sempere, R. and Kawamura, K.: Comparative contributions of dicarboxylics acids and related polar compounds in snow, rain and aerosols from urban atmosphere, Atmos. Environ., 28, 449-459, 1994.

Strader. R., Lurmann, F., and Pandis, S. N.: Evaluation of secondary organic aerosol formation in winter, Atmos. Environ., 33, 48494863, 1999.

Sullivan, A. P., Weber, R. J., Clements, A. L., Turner, J. R., Bae, M. S., and Shauer, J. J.: A method for on-line measurements of water soluble organic carbon in ambient aerosol particles: Results from an urban site, Geophys. Res. Lett., 31, L13105, doi:10.1029/2004GL019681, 2004.

Tsigaridis, K. and Kanakidou, M.: Global modelling of secondary organic aerosol in the troposphere: a sensitivity analysis, Atmos. Chem. Phys., 3, 1849-1869, 2003,

\section{SRef-ID: 1680-7324/acp/2003-3-1849.}

Turpin, B. J.: Options for characterizing organic particulate matter: new research strategies could help elucidate the mechanisms and causes of aerosol health effects, Environ. Sci. Technol., 33, 76A79A, 1999.

Yang, H., Yu, J. Z., Ho, S. S. H., Xu, J., Wu, W. S., Wan, C. H., Wang, X., Wang, X., and Wang, L.: The chemical composition of inorganic and carbonaceous materials in $\mathrm{PM}_{2.5}$ in Nanjing, China, Atmos. Environ., 39, 3735-3749, 2005.

Zappoli, S., Andracchio, A., Fuzzi, S., Facchini, M. C., Gelencsér, A., Kiss, G., Krivácsy, Z., Molnár, A., Mészáros, E., Hansson, H. C., Rosman, K., and Zebühr, Y.: Inorganic, organic and macromolecular components of fine aerosol in different areas of Europe in relation to their water solubility, Atmos. Environ., 33, 2733 $2743,1999$. 